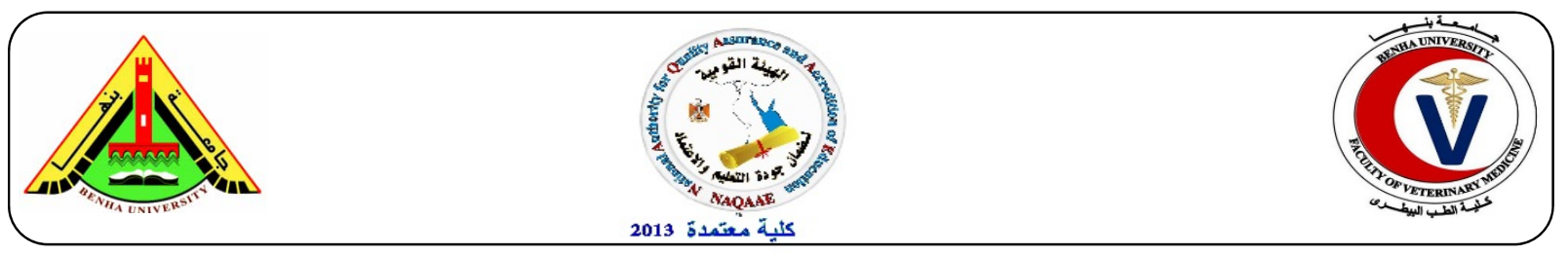

\title{
Detection of Shiga toxin produced by Escherichia coli in poultry and meat in Luxor city using multiplex PCR
}

\author{
Jehan, R. Daoud ${ }^{1}$, Karmi, Mohamed ${ }^{2}$, Soad, A. Nasef ${ }^{3}$, and Reham, Y. Ahmed ${ }^{3}$ \\ ${ }^{1}$ Faculty of Vet Medicine, South Valley Uni. \\ ${ }^{2}$ Faculty of Vet Medicine, Aswan Uni. \\ ${ }^{3}$ Reference Lab. For Vet. Quality control on poultry production.
}

\begin{abstract}
A B S T R A C T
Shiga toxins were widely spread in the meat especially in minced meat. These toxins have an important significance to human health because it is a major cause of food poisoning. About 150 meat samples purchased from a number of supermarkets and butcher shops in Luxor city were examined for presence of E. coli (50 raw meat samples - 50 minced meat samples - 50 sample of chicken meat). 62 samples were positive for E.coli spp. 26 isolates were confirmed serologically using $\mathrm{O} \& \mathrm{H}$ specific antisera as E.coli. Incidence of E. coli was in chicken meat $6 / 50(12 \%)$ and raw meat $11 / 50(22 \%)$ and minced meat $9 / 50(18 \%)$. 26 E. coli isolates tested serology using special antisera $(\mathrm{O} \& \mathrm{H})$ recognize that there are 12 genetic groups They are O26: H11, O114: H21, O119: H4, O2: H6, O125: H21 in chicken meat. O111: H2, O55: H7, O125: H21, O128: H2, O26: H11, O124 in raw meat. In minced meat O128: H2, O119: H4, O44: H18, O26: H11, O111: H2, O78, O55: H7. E.coli O111,O26 and O119 the most prevalent serotype. Polymerase chain reaction was used to detect virulence genes in isolated strains stx1, stx2, eaeA.
\end{abstract}

Keywords: E. coli, stx1, stx2, eaeA.

(http://www.bvmj.bu.edu.eg)

(BVMJ-31(2): 40-44, 2016)

\section{INTRODUCTION}

Escherichia coli is a normal inhabitant of the intestinal tract of humans and warm-blooded animals. Its presence in raw foods is considered an indication of direct or indirect fecal contamination. Thus, it is used as an indicator organism for possible presence of enteric pathogens in food and water (Cohen et al., 2007). It is an important organism in the food microbiology; besides being involved in food borne gastroenteritis, it is considered a good indicator of possible faecal contamination as this species normally live in the intestines of humans and animals (ICMSF, 1982). E. coli may contaminate foods in a variety ways, including bowel rupture during evisceration, indirect contamination with sewage and polluted water, and handling and packaging of finished products (Schroeder et al., 2004). Meats are a common source of $E$. coli contamination, which may be acquired during slaughter through fecal contact (Cohen et al., 2007). E. coli cause intestinal infections such as diarrhoea or haemorrhagic colitis, or cause extra-intestinal infections such as neonatal meningitis, nosocomial septicaemia, haemolytic uremic syndrome, urinary tract and surgical site infections (Falagas and Gorbach, 1995). Several classes of $E$. coli were recognized specifically enteroinvasive E.coli (EIEC), entero toxigenic E.coli (ETEC), Shiga like toxin-producing (STEC) or entero hemorrhagic E.coli (EHEC) or verotoxin producing E.coli (VTEC), enteroaggregative E.coli (EAggEC) (Nataro and Kaper, 1998).

STEC has a confirmed zoonotic origin among different groups of pathogenic E.coli with ruminants, especially cattle, as the major reservoir for human infections. STEC are the most devastating and a major public health concern for its association with large foodborne outbreaks and life-threatening hemolytic uremic syndrome (HUS). More than 400 different serotypes of VTEC have been isolated from humans but only few are associated with the majority of human EHEC cases (Scheutz and Strockbine, 2005). Virulence factors for non-O157 STEC include production of the shiga-like toxins 1 and/or 2 (stx 1 , $s t \times 2$ ) and intimin (eaeA). Cattle and other ruminants appear to be the main reservoir of nonO157 STEC, as well as the O157:H7 serotype. 
With carriage rates of non-O157 STEC in cattle being a public health concern, a method was devised to detect and isolate the six major nonO157 STEC serogroups (O26, O45, O103, O111, $\mathrm{O} 121$ and $\mathrm{O} 145)$ in ground beef and beef trim (Arthur et al., 2002).

In the sight of these facts, the aim of this study was to record the incidence of STEC in meat samples collected from Luxor city

\section{MATERIAL AND METHOD}

\subsection{Collection of samples:}

A total of 150 samples of ( 50 chicken meat -50 raw meat 50 minced meat) were collected during the period from November 2014 to April 2015 from butchers, meat retailers and supermarkets in Luxor Governorate.

\subsection{Isolation of E. coli}

It was done according to Quinn et al. (1994).

\subsection{Serotyping of E. coli Isolates}

E. coli isolates were sero-grouped according to Kok et al. (1996) using rapid diagnostic E. coli antisera sets (DIFCO Laboratories, Detroit Michigan 48232-7058, USA) at Food Analysis Center, Faculty of Veterinary Medicine, Benha University, Egypt.

The serologically identified $E$. coli isolates were analyzed for the presence ofstx 1 and stx 2 genes. Genomic DNA was extracted from each E. coli isolate using Bacterial DNA extraction kit (Spin-column) (BioTeke Corporation, Catalogue, DP2001) according to the manufacturer's instructions.

\subsection{Polymerase chain reaction (PCR)}

The confirmation of isolated strains and detection of shiga toxin1 (stx1 gene) and shiga toxin2 (stx2 gene) and eae A gene were done according to EL-Jakee et al. (2009).

Table (1) The primers used in PCR

\begin{tabular}{|c|c|c|c|}
\hline Gene & Primer Sequence5'-3' & Amplified size (pb) & References \\
\hline \multirow[t]{2}{*}{ eaeA } & GACCCGGCACAAGCATAAGC & $384 \mathrm{bp}$ & (EL-Jakee et al., 2009) \\
\hline & CCACCTGCAGCAACAAGAGG & & \\
\hline \multirow[t]{2}{*}{ stx 1} & ACACTGGATGATCTCAGTGG & $614 \mathrm{bp}$ & \\
\hline & CTGAATCCCCCTCCATTATG & & (Chassagne et al., 2009) \\
\hline \multirow[t]{2}{*}{ Stx 2} & CCATGACAACGGACAGCAGTT & $779 \mathrm{bp}$ & \\
\hline & CCTGTCAACTGAGCAGCACTTTG & & \\
\hline
\end{tabular}

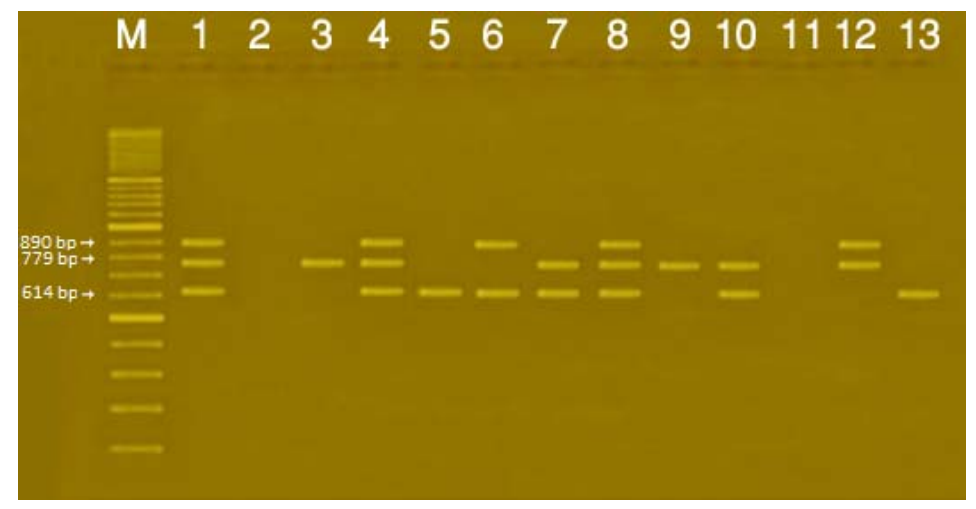

Fig (1): Agarose gel electrophoresis of multiplex PCR of stx1 (614 bp), stx2 (779 bp) and eaeA (890 bp) genes for characterization of Enteropathogenic E.coli. Lane M: $100 \mathrm{bp}$ ladder as molecular size DNA marker. Lane 1: Control positive for st $x 1, s t \times 2$ and eaeA genes. Lane 2: Control negative for stx 1 , st $x 2$ and eaeA genes. Lanes $3 \& 9$ (E.coli O2 \& O114): Positive strains for stx2 gene. Lanes 4 \& 8 (E.coli O26 \& O111): Positive strains for $s t x 1$, st $x 2$ and eaeA genes. Lanes $5 \& 12$ (E.coli O44 \& O128): Positive strains for $s t x 1$ gene. Lane 6 (E.coli O55): Positive strain for stx 1 and eaeA genes. Lane $7 \& 10$ (E.coli O78 \& O119): Positive strains for $s t x 1$ and $s t x 2$ genes. Lane 11 (E.coli O124): Negative strain for $s t x 1$, st $x 2$ and eaeA genes. Lane 12 (E.coli O125): Positive strain for st $x 2$ and eaeA genes. 


\section{RESULTS}

E. coli is one of the most important food poisoning bacteria and has an important indication in food hygiene. E. coli spp. could be isolated in 62 samples form a total 150 collected samples. 26 isolates were confirmed serologically using $\mathrm{O} \& \mathrm{H}$ specific antisera as E.coli serovars. Incidence of $E$. coli was in chicken meat $6 / 50(12 \%)$ and raw meat $11 / 50(22 \%)$ and minced meat $9 / 50(18 \%)$.

26 E. coli isolates tested serology using special antibodies $(\mathrm{O} \& \mathrm{H})$ recognize that there are 12 genetic groups followed these 26 isolates using these antibodies. Found O26: H11, O114: H21, O119: H4, O2: H6, O125: H21 in chicken meat. O111: H2, O55: H7, O125: H21, O128: H2, O26: $\mathrm{H} 11, \mathrm{O} 124$ in raw meat. O128: $\mathrm{H} 2, \mathrm{O} 119: \mathrm{H} 4$, O44: H18, O26: H11, O111: H2, O78, O55: H7 in minced meat. serotypes O111, O26 and O119 the most prevalent serovars.

\section{DISCUSSION}

Six out of the 50 chicken samples investigated for the presence of $E$. coli by percentage $12 \%$. The prevalence of $E$. coli in chicken samples $12 \%$ was nearly similar with that was reported by Momtaz et al. (2012) and Zende et al. (2013) who reported that the incidence of E.coli in chicken meat was $11 \%$ and $16.67 \%$, respectively. On the other hand, the present results were lower than those reported by Hyun-jung et al. (2015) and Nguyen et al. (2016) who reported E.coli presented in chicken meat with percentage $75.9 \%$ and $92.7 \%$, respectively. These differences could be attributed to the hygienic measures proceeded in different localities under investigation and health condition of the meat handlers.

The incidence of E.coli in the examined meat samples was $22 \%$ ( 11 out of 50 examined samples). Concerning to previous work, the prevalence of the isolated E.coli was reported in meat samples examined by Momtaz et al. (2012) and Farhan et al. (2014) was $29 \%, 30 \%$, respectively. Higher prevalence was reported by Patricia et al. (2014) and Hyun-jung et al. (2015) who isolated E.coli with percentage $36.1 \%, 42.3 \%$, respectively. On the other hand, lower recovery rates were recorded of $12.5 \%$ by Sethulekshmi et al. (2016). The presence of E.coli as intestinal commensal organism in human and animal resulting from faecal contamination or contamination during food animal slaughter it is often found in soil, water and foods (Riley et al., 1983) and this responsible for the highest result in this study.

Concerning to minced meat samples, 9 out of 50 samples with the isolation rate of $18 \%$ were recorded. It was in close agreement with the previous results of Panahee and Pourtaghi (2016) who isolated E.coli with percentages $23.5 \%$ respectively. Higher results were reported by Badri et al. (2009) who isolated E.coli with percentage $45 \%$ and $42.5 \%$, respectively. While, lower result was reported by Wenting et al. (2012) who isolate E.coli by percent $5.2 \%$ in minced meat.

Serotyping is a common way to characterize STEC strains, and is based on the $\mathrm{O}$ antigen (somatic antigen) and $\mathrm{H}$ antigen (flagellar antigen) (Gyles, 2007). The most common EHEC serogroup are: $\mathrm{O} 4, \mathrm{O} 5, \mathrm{O} 16, \mathrm{O} 26, \mathrm{O} 46, \mathrm{O} 48, \mathrm{O} 55, \mathrm{O} 91, \mathrm{O} 98$, O111ab, O113, O117, O118, O119, O125, O126, O128, O145, O157 and O172. Recently, several new EHEC serogroup have been described: O176, O177, O178, O179, O180 and O181 (Scheutz and Strockbine, 2005). The data showed that the isolated serotypes in chicken meat were O26 (2), O114 (1), O119 (1), O2 (1) and O125 (1). O26 reported the highest serotype present. This result was nearly similar to results of Kudakwashe et al. (2013) and agree with Zende et al. (2013) in $\mathrm{O}_{2}$ serotype only.

On the other hand, the isolated serotypes in raw meat were (3) O111, (3) O55, (2) O125, (1) O128, (1) O26 and (1) O124. Such results were nearly similar to Al-Zogibi et al. (2015) who isolated O111 but other serotypes (O157, O174, O22). While, STEC of serogroup O157, O26, O111 were not found. In addition, Bergey's manual of systematic bacteriology (2005) and Karmali et al. (2003) who reported that there are 300-400 known STEC serotypes, but not all of them have been associated with human illness. STEC can be found in soil, water, and food vehicles.

The isolated serotypes in minced meat were O128 (3), O119 (1), O44 (1), O26 (1), O111 (1), $\mathrm{O} 78$ (1) and $\mathrm{O} 55$ (1) with the highest percentage is O128 (33\%). Related serotypes O55 and O111 recorded with rate $22 \%, 30 \%$, respectively. While lower recovery rates were recorded $2.6 \%$ by Perelle et al. (2007) On the other hand, higher result recorded with rate $46 \%$.

Multiplex PCR was reported to be more sensitive and accurate for determination of Shiga toxin-producing Escherichia coli gene in foods. Multiplex PCR reported the presence of $s t x 1$, st $x 2$ and eaeA genes in chicken meat samples with rate 
of $33 \%, 83 \%$ and $33 \%$, respectively with the incidence of Shiga toxin producing E. coli of $12 \%$. Lower percent of STEC isolated by Abdul Razzaq et al. (2013) was $2 \%$ of chicken meat. Stx 2 percent which detected in this study (83\%) was higher than that recorded by Panahee and Pourtaghi (2016) and Zende et al. (2013) which was $21 \%, 27 \%$ respectively. The present data showed that STEC results in raw meat $45 \%$ St $x 1 ; 36 \%$ Stx 2 and $36 \%$ eae A. Patricia et al. (2014) reported that percent of virulence gene $5.3 \%$ St $x 1 ; 86.0 \%$ Stx $2 ; 26.3 \%$ eae A. $50 \%$ St $x 1,61 \%$ St $x 2$ and $9 \%$ eae A gene were detected in some reports. It is clear that Stx2 is higher than $S t x 1$ but in the current study, Stx 1 is higher than Stx2. Al-Zogibi et al. (2015) reported highly percent of virulence gene Stx of $94.12 \%$ in serotype of $E$. coli recovered from meat samples. On the other hand, eae A gene was detected in $58.82 \%$. Sethulekshmi et al. (2016) found $57 \%$ Stx $1,57 \%$ Stx 2 with absence of eae A gene. This high result of shiga toxin indicates high level of contamination. Dhanashree and Shrika (2007) isolated 40 eae A of 103 meat samples, the heighest percent of eae A gene due to decreasing of STEC strains. Hyun-jung et al. (2015) isolated 25 STEC strains from meats, five strains $(20 \%)$ were positive for the eae A gene, $80 \%$ Stx, Stx2. on the other hand, Abdul Razzaq et al. (2013) isolated STEC in meat with low percent $(1 \%)$ and confirmed by PCR.

\section{CONCLUSION}

From achieved results, the highest percentage of E.coli was presented in raw meat by percentage $22 \%$ and the lowest one was found in chicken $12 \%$. The highest result of shiga-toxin producing E.coli was detected in raw minced meat due to exposure of minced meat to several processes. stx 1 was found in chicken meat by percentage $33 \%$, st 22 $83 \%$ and eae A gene $33 \%$. While in raw meat, the results were $45 \%$ st $x 1,36 \%$ st $x 2$ and $36 \%$ eae A gene. In minced meat, they were found $77 \%$ stx 1 , $44 \%$ st $x 2$ and $33 \%$ eae A gene.

\section{REFERENCES}

Abdul Razzaq, M.I., Mashkoor, M., Malik, K.A., 2013. Molecular diagnostics of foodborne pathogens Pure and Applied Biology 2, 6975.

Al-Zogibi, O.G., Mohamed, M.I., Hessain, A.M., El-Jakee, J.K., Kabli, S.A., 2015. Molecular and serotyping characterization of shiga toxogenic Escherichia coli associated with food collected from Saudi Arabia. Saudi J Biol Sci 22, 438-442.

Arthur, T.M., Barkocy-Gallagher, G.A., RiveraBetancourt, M., Koohmaraie, M., 2002. Prevalence and characterization of nonO157 Shiga toxin-producing Escherichia coli on carcasses in commercial beef cattle processing plants. Appl Environ Microbiol 68, 4847-4852.

Badri, S., Filliol, I., Carle, I., Hassar, M., Fassouance, A., Cohen, N., 2009. Prevalence of virulence genes in Escherichia coli isolated from food in Casablanca (Morocco). Food Control 20, 560-564.

Bergey's manual of systematic bacteriology, 2005. The Proteobacteria.

Chassagne, L., Pradel, N., Robin, F., Livrelli, V., Bonnet, R., Delmas, J., 2009. Detection of stx1, stx2, and eae genes of enterohemorrhagic Escherichia coli using SYBR Green in a real-time polymerase chain reaction. Diagnostic microbiology and infectious disease 64, 98-101.

Cohen, N., Ennaji, H., Bouchrif, B., Hassar, M., Karib, H., 2007. Comparative study of microbiological quality of raw poultry meat at various seasons and for different slaughtering processes in Casablanca (Morocco). J Appl Poultry Res 16, 502-508.

Dhanashree, B., Shrika, M.P., 2007. Detection of shiga-toxigenic Escherichia coli (STEC) in diarrhoeagenic stool \& meat samples in Mangalore, India. Indian J Med Res 128, 271-277.

EL-Jakee, J., Moussa, E., Mohamed, K., Mohamed, G., 2009. Using Molecular techniques for characterization of Escherichia coli isolated from water sources in Egypt. Global Veterinaria 3, 354362.

Falagas, M.E., Gorbach, S.L., 1995. Practice Guidelines - Urinary-Tract Infections. Infectious Diseases in Clinical Practice 4, 241-257.

Farhan, R.S., Abdalla, H.A., Abdelrahaman, N.F., Salama, E., 2014. Prevalence of Escherichia coli in some selected foods and children stools with special reference to molecular characterization of enterohemorrhagic strain. American Journal of Animal and Veterinary Sciences 9, 245- 251.

Gyles, C.L., 2007. Shiga toxin-producing Escherichia coli: an overview. J Anim Sci 85, E45-62.

Hyun-jung, P., Jang, W.Y., Eun-Jeong, H., EunKyoung, K., Ki-Yeon, K., Young-Jo, K., Hyang-Jin, Y., Sung-Hwan, W., Yong Ho, 
P., Jin, S.M., 2015. Antibiotic resistance and virulence potentials of shiga toxinproducing Escherichia coli isolates from raw meats of slaughterhouses and retail markets in Korea. J. Microbiol. Biotechnol. $25,1460-1466$.

ICMSF, 1982. International Committee on Microbiological specification for food. Their significance and methods of enumeration, 2 nd ed. Univ. of Toronto press, Toronto. Buffalo\& London.

Karmali, M.A., Mascarenhas, M., Shen, S., Ziebell, K., Johnson, S., Reid-Smith, R., IsaacRenton, J., Clark, C., Rahn, K., Kaper, J.B., 2003. Association of genomic O island 122 of Escherichia coli EDL 933 with verocytotoxin producing Escherichia coli seropathotypes that are linked to epidemic and/or serious disease. J Clin Microbiol 41, 4930-4940. .

Kok, T., Worswich, D., Gowans, E., 1996. Some serological techniques for microbial and viral infections. In Practical Medical Microbiology (Collee, J.; Fraser, A.; Marmion, B. and Simmons, A., eds.), 14th ed, Edinburgh, Churchill Livingstone, UK.

Kudakwashe, M., Huu, A.D., Edward, W., Mills, C.N., Cutter, E.L., Roberts, C.D., 2013. Incidence of Shiga toxin-producing Escherichia coli strains in beef, pork,chicken, deer, boar, bison, and rabbit. Journal of Veterinary Diagnostic Investigation 25, 254-258.

Momtaz, H., Rahimi, E., Moshkelani, S., 2012. Molecular detection of antimicrobial resistance genes in E. coli isolated from slaughtered commercial chickens in Iran. Veterinarni Medicina 57, 193-197.

Nataro, J.P., Kaper, J.B., 1998. Diarrheagenic Escherichia coli. Clinical Microbiology 11, 142-201.

Nguyen, D.P., Nguyen, T.A.D., Le, T.H., Tran, N.M.D., Ngo, T.P., Dang, V.C., Kawai, T., Kanki, M., Kawahara, R., Jinnai, M., Yonogi, S., Hirai, Y., Yamamoto, Y., Kumeda, Y., 2016. Dissemination of Extended-Spectrum beta-Lactamase- and AmpC beta-Lactamase-Producing Escherichia coli within the Food Distribution System of Ho Chi Minh City, Vietnam. Biomed Research International 12, 719-725.
Panahee, M., Pourtaghi, H., 2016. Virulence gene profiles of Shiga-toxin producing Escherichia coli isolates from retail raw meat in Iran. Bulg. J. Vet. Med. , 1311-1477.

Patricia, L., Laura, B., Kinue, I.M., Valeria, R., Adriana, B., 2014. Characterization of shiga toxin-producing Escherichia coli isolated from ground beef collected in different socioeconomic strata Markets in Buenos Aires, Argentina. Instituto Adolfo Lutz, Sao Paulo, SP, Brazil.

Perelle, S., Dilasser, F., Grout, J., Fach, P., 2007. Screening food raw materials for the presence of the world's most frequent clinical cases of Shiga toxin-encoding Escherichia coli O26, O103, O111, O145 and O157. International Journal of Food Microbiology 113, 284-288.

Quinn, P.J., carter, M.E., Markey, B.K., Carter, G.R., 1994. Clinical Veterinary Microbiology. Mosby Wolfe 14, 4251-4255.

Riley, L.W., Remi, R.S., Helgerson, S.D., McGee, H.B., Wells, B.K., Davis, R., Hebert, J., Olcott, E.S., Johnson, L., Hargrett, N.T., Blake, P.A., Cohen, M.L., 1983. Haemorrhagic colitis associated with a name E. coli serotype. New England Medicine 24, 681-685. .

Scheutz, F., Strockbine, N.A., 2005. Genus I. Escherichia. In: Brenner, D.J., et al. (Eds.) The Protebacteria Part B The Gammaproteobacteria. Springer.

Schroeder, C.M., White, D.G., Meng, J., 2004. Retail meat and poultry as a reservior of antimicrobial-resistant Escherichia coli. Food Microbiol 21, 249-255.

Sethulekshmi, C., Latha, C., Sunil, B., 2016. Occurrence of Enterohaemorrhagic E. coli in raw meat samples in Kerala. Int. J. Adv. Res. Biol. Sci. 3, 220-222.

Wenting, J.u., Jinling, S., Yi, L., Magaly, A.T., Shaohua, Z., Sherry, A., Mohamed, B.N., Jianghong, M., 2012. Non-O157 Shiga toxin-producing Escherichia coli in retail ground beef and pork in the Washington D.C. area. Food Microbiology 32, 371-377.

Zende, R.J., Chavhan, D.M., Suryawanshi, P.R., Rai, A.K., Vaidya , V.M., 2013. PCR detection and serotyping of enterotoxigenic and shigatoxigenic Escherichia coli isolates obtained from chicken meat in Mumbai, India. Veterinary World 6, 770-773. 